Canadian University Music Review

Revue de musique des universités canadiennes

\title{
Stephen C. Willis. Alexis Contant: Catalogue. Ottawa: National Library of Canada, 1982, viii, 87 pp.
}

\section{Barclay McMillan}

Numéro 4, 1983

URI : https://id.erudit.org/iderudit/1013911ar

DOI : https://doi.org/10.7202/1013911ar

Aller au sommaire du numéro

\section{Éditeur(s)}

Canadian University Music Society / Société de musique des universités canadiennes

\section{ISSN}

0710-0353 (imprimé)

2291-2436 (numérique)

Découvrir la revue

Citer ce compte rendu

McMillan, B. (1983). Compte rendu de [Stephen C. Willis. Alexis Contant: Catalogue. Ottawa: National Library of Canada, 1982, viii, 87 pp.] Canadian University Music Review / Revue de musique des universités canadiennes, (4), 335-336. https://doi.org/10.7202/1013911ar

(c) Canadian University Music Society / Société de musique des universités canadiennes, 1983
Ce document est protégé par la loi sur le droit d'auteur. L'utilisation des services d'Érudit (y compris la reproduction) est assujettie à sa politique d'utilisation que vous pouvez consulter en ligne.

https://apropos.erudit.org/fr/usagers/politique-dutilisation/ 
STEPHEN C. WILLIS. Alexis Contant: Catalogue. Ottawa: National Library of Canada, 1982, viii, $87 \mathrm{pp}$.

Somewhere near the middle of the clump of attitudes and assumptions that contribute to the still general apathy and ignorance about the past of musical composition in Canada lies a problem of perception. We are accustomed to thinking of composition in this country as a purely twentieth-century phenomenon with only three identifiable generations of composers: the "first generation" uttering an autumnal romantic rhetoric, the "middle generation" introducing to Canada the new techniques of contemporary musical enterprise, and later passing these on to their own pupils, the "third generation." However convenient such facile nomenclature may be, our acceptance of it does no more to stimulate curiosity about generations of Canadian composers before the turn of the century than the fundamentalist's reliance on the myth of Adam and Eve promotes the quest for the origins of mankind. If we are sure about who were "the first," there is not much incentive, really, to wonder about anyone who came from the logically impossible "before."

The disservice this perception does to hardy pioneers who did, in fact, run before-effectively obliterating not only their music but also the memory of them as contributors to the continuum of Canadian musical life-is Helmut Kallmann's starting point in the preface he contributes to Stephen Willis's catalogue. The "middle generation" composers, among whom the three-generation classification arose, really belong, he points out, not to the second generation, but to the third or fourth. Some dozen competent composers born during the three decades immediately preceeding Confederation produced a substantial body of music for church, theater, and concert hall-music which cannot be ignored if we are to reach a mature awareness of the progress of composition in this country.

Publication of the work in hand brings that awareness a step closer. Montreal composer Alexis Contant (1858-1918), whose life and music is the subject of the catalogue, made a unique contribution to the literature of this earlier generation. Working entirely in a Canada still lacking the professional resources needed for regular musical performance and never having had the stimulus of training abroad, he nevertheless produced an ouvre remarkable in its scope-even by today's standards. The catalogue is designed to open up that ouvre both to the possibility of renewed performance, and to the critical attention it deserves.

To that end Willis, Head of the Manuscript Collection of the National Library of Canada's Music Division and custodian of the Contant papers, has spared no pains. The catalogue (based primarily, though not exclusively, on the Contant papers held at the National Library) is truly comprehensive in scope, and thoroughly useful in 
arrangement. The musical works, including not only Contant originals but his arrangements of other composers' music, are grouped in eleven categories and listed in chronological order within each category. A reference number is assigned each composition as an aid to cross reference. The descriptive details are full, including not only titles but subtitles, first lines of text, and whatever other features may be useful in identifying a particular work. Authors of texts are identified, as well as composers of music that Contant has arranged. Scoring is indicated, and the titles of individual movements are given. The entries are accompanied by historical notes giving the date of composition, information about origin, dedication, first performance, and relationship to the composer's other works. The entries also include details and location of holographs and, where applicable, particulars of publication. Lists of audio material are included: commercial recordings of Contant's music, as well as tapes held at the National Library, the CBC Program Archives in Montreal, and the Montreal branch of the Canadian Music Centre.

The research value of the Contant catalogue is greatly enhanced by the inclusion of bibliographies, and lists of archival material held at the National Library and in the personal collection of Jean-Yves Contant of Montreal, a grandson of the composer. These include correspondence, programs, newspaper clippings, photographs, holdings surviving from Contant's personal music library, and other documents contributing to an understanding of the cultural milieu that was the pioneer composer's inspiration. A "Calendar", listing events related to Contant's life and music in chronological order, from birth in 1858 to the revival of his oratorio, Caïn in 1980, provides a convenient orientation for the historical context. Indexes-Author/Composer and Title/ First Line-complete a reference work exemplary both in scholarship and presentation.

The catalogue, a publication of the National Library of Canada, attractively illustrated with pertinent photographic material, is issued in a bilingual format with the French text separate from the English and printed on inverted pages. Obviously a valuable reference tool for libraries, a copy should also be kept within easy reach of everyone engaged in researching and promoting nineteenth-century Canadian music.

Barclay McMillan

Johann KuHnaU. Six Biblical Sonatas. Hilda Jonas: Harpsichord. Sanjo-Music HJ 1004-1, 2, 3, 4 (1982). (Available from: SanjoMusic, P.O. Box 16422, San Francisco, California 94116.)

Johann Jacob Kuhnau (1660-1722), J. S. Bach's immediate predecessor as Thomaskantor in Leipzig, is perhaps best known as the composer 